\title{
Populism Is Not the Only Trend
}

\author{
Shana Cohen ${ }^{1}$
}

Published online: 19 May 2018

(C) Springer Science+Business Media, LLC, part of Springer Nature 2018

In the summer of 2016, I had to spend a bit of time in the hospital. It was after David Cameron's resignation and the Brexit vote. When one of my doctors came into my room for a chat, I asked him how he felt, as an employee of a health service so dependent on migration, about the implications of the Brexit vote. He retorted, "It has brought out elements of our society that were better left covered up". His comment resonated with discussions I had had that summer, where when colleagues and friends expressed their shock at how neighbours and relatives were responding to Brexit. One colleague recounted a story of neighbours asking local Spanish residents when they were leaving to "return home".

Much of media attention since Brexit, Trump, and subsequent European elections that saw gains for far-right parties (e.g. Germany and Austria) has been on the rise of populism (Goodwin 2011, 2017; Martinelli 2016) or nativism (Mudde 2007, 2012, 2017; Guia 2016). Protests about migration, such as the Pegida marches in Germany (Goodwin and Milazzo 2017) and the broader mobilization of far-right movements in Europe and the USA are attributed to the decline of industries and public sector investment in regions and states far away from the wealth of large, diverse cities. The political base for current populism or nativism is, as one of the most prominent analysts of the far right, Cas Mudde, explains, "members of the native group ("the nation")", who are threatened by "non-native people and ideas are fundamentally threatening to the homogenous nation-state" (2017).

Despite the association with post-industrialization and economic decline, in some ways, the political logic of far-right movements resembles the strategy of post-colonial governments, when authoritarian regimes maintained power through alliances with particular social and economic groups (Cohen 2004). These alliances reified a set of values associated with nationalism, economic security, and exclusion of minority ethnic groups and low-income populations (Ashcroft et al. 1995). Market reform and more recently, austerity measures, weakened these alliances, as the state lost its capacity to ensure economic security and intergenerational social reproduction.

Yet, the dominant focus on far-right reactions to industrial decline, migration, and "liberal values" has obscured another trend, or that of local efforts to promote solidarity, particularly

Shana Cohen

scohen@tasc.ie 
with migrants, and freedom of expression, especially amongst individuals whose rights are under consistent threat, both from policy initiatives and media debates. The latter most obviously has included Muslim women, refugees, and welfare recipients. In contrast to farright movements, however, this trend has remained stubbornly local, grounded in community groups, religious institutions, and individual activism. It lacks articulation at a national level and likewise, connection to the sustainability of democratic institutions, equal representation, and economic redistribution.

Arguing for the renewal of participatory democracy, and citing the absence of options beyond elections, Hollie Russon Gilman states that in the USA that the

challenge to engaging community residents in civic life beyond simply voting every two or four years is that there is no consensus about what a more robust, participatory model of democracy_ one in which people more actively participate in the civic fabric of their community-looks like in the United States. (2017)

Indeed, efforts at promoting citizenship, including the method that Gilman in particular champions - participatory budgeting, often assume a connection between specific mechanisms for providing input into public services and the more complex, less tangible perception of belonging to a political collectivity. Like local activism to foster solidarity, these mechanisms, ranging from participatory budgeting, which involves citizen input into local government budgeting decisions, to citizen report cards, which provide service users a means to provide feedback on public services, allow residents to influence their environment. They are not situated within a narrative of sustaining democratic institutions or how individual action contributes to the concept of public good and the significance of this concept for political inclusion. In other words, they do not, as Artaud de la Ferriere points out, make the jump from a "regime of love" to a "regime of justice".

The articles in this volume document local efforts at solidarity and indicate how the rise of far-right movements in part reflects the same frustration with state capacity and budget cuts as local social activists aiming to help migrants integrate rather than pushing them away. The inadequacies of public services have led to greater dependence on faith-based organizations, but the effect of this dependence on community isolation is ambiguous (see Everett in this issue). The more significant question is whether or not these efforts can become more coherent at a national level and offer an alternative politics that focuses on restoring the capacity of public institutions and their ability to address the needs of every citizen, regardless of background.

\section{Migrants and Civic Activism in Europe}

The six papers in this issue trace an immediate, and thus shifting, negotiation with the presence of migrants in Europe. The authors examine different public and private responses across countries, institutions, political parties, and religious beliefs. Their papers present no clear trajectory to how European governments can devise migration policies acceptable to citizens possessed of increasingly divergent views. The divergence appears locally and sometimes within the same organizations and institutions, diminishing the potential for national, or even local, governments to find allies in the general public.

The debate around migration, though focused on number and evidence (or lack of) integration, reveals a more profound dissonance in modes of self-reflection and collective 
aspirations. In her paper, Manuela Bojadzijev shows how migration to Germany has become "a social seismograph through which to assess broader social discourse, introspections, as well as visions of community, insofar as migration has become figurative for vital negotiations and polarisations on belonging". Migration, which has come late to Germany compared with countries like Britain and France, has challenged "the borders of community in the context of an increasingly global economy".

Borders have become a matter of contention, whether to secure physical exclusion or to integrate all those within them into a single entity. The latter can refer to an area of movement, like the Schengen Zone, or a national identity. More profoundly, borders challenge or underpin the evolution of the global economy and free movement of trade and labour. Anti-migration sentiments call for closed borders and inward-looking economic policies whereas promigration arguments, or at least those favouring more open borders, point to issues like labour shortages and needed skills as benefits migrants bring to host countries. A third voice has regarded migration as a means to reflect on the evolution of democracy and collective progress across borders, in that both the factors the at led to migration and the political responsibility of host nations are not ignored. In the end, as Bojazdijev remarks, "many arguments within this heated debate actually have little or nothing to do with migration whatsoever, but rather speak to the degree of required democratisation".

Kasia Narkowicz's article concurs, noting that migration levels to Poland are far below those to other European countries, but the threat of the "Other" has come to justify nationalism and the present government's positions. She writes that the "Polish response to the so-called refugee crisis should be analysed as a subtext to the broader political changes in the country, whereby the figure of the Muslim terrorist disguised as a refugee has allowed the government to advance its nationalistic agenda aiming to exclude all that is considered 'foreign'". The increasing hostility toward religious minorities and the role of clergy and politicians in stoking suspicion of refugees and migrants reflects for her, as with Bojazdijev, a more profound anxiety about democracy. What values do democratic institutions represent and whom do they serve? Where are the fault lines of contention and what are the political implications of tensions between the dominant institutions (church, state) and individual or communitybased actors, for instance Muslim organizations and LBGTQ groups?

Jan-Jonathan Bock's article also shares the same understanding of the politics of migration, or that it reflects deeper frustrations with the state and national politics. He argues that the refugee situation has revealed a lack of trust in public administration in Germany, as the state has proven incapable of managing a dramatic change, in this case, the inflow of approximately a million refugees. Pursuing in more depth the indication Narkowicz gives of emerging political divides, Bock stresses the importance of civil society actors in assuming responsibility for refugee integration and expressing political values of inclusion and diversity. Their greater confidence and growing presence in the public sphere have coincided with the emergence of a much more vocal nationalist, right wing response, one that has taken advantage of the state's weaknesses to call for greater exclusion and rejection of "foreigners".

Bock points specifically to the long-term effects of austerity measures, where cuts to public services have reduced the capacity of the state to respond effectively both to crises and ongoing need for public services. The inability to cope with applications from the influx of migrants, as well as provide them with accommodation and eventually, mechanisms of integration, has revealed both the deficiencies within the public administration and the failure of the private sector to substitute for state provision. In addition, the shortcomings in state 
action concerning refugees have exposed the inadequacy of public policy responses to cultural and religious diversity and the status of minority faiths.

The other articles delve more closely into the experience of migration and local activism either to support new migrants or strengthen means of self-expression amongst citizens of migrant origins. Analyzing church-based activism in La Goutte d'Or, a densely populated area of Paris with a large migrant population, Alexis Artaud de la Ferriere utilizes Luc Boltanski's matrix of four regimes of action that are "organised according to actors' relationship to each other and to their surrounding physical and institutional environment". These regimes include justice, violence, routine, and love, and He looks in particular at the regime of love, which "are motivated by individual sentiment and personal intention, rather than by convention and obligation" and thus cannot be sustained on a long-term basis. The volunteers for church activities are motivated largely because of their religious beliefs or the inspiration the church provides in its internal culture to "do good". Yet, as Artaud de la Ferriere finds, individual or even group sentiment has difficulty translating into political activism to change government migration and refugees policies or counter discrimination. Local action remains local. Loosely organized, motivated by desire for a notion of greater equality and justice, volunteers express their own convictions in immediate service, revealing the political limitations of charity and, perhaps, the counter-trends to current far-right movements.

Samuel Everett's article offers an opposing perspective, illustrating how the national state of emergency in France and the politics of laïcité constrain the capacity of local activism in Paris, particularly efforts to bring together members of different faiths, to instigate change. Based on field research in another area of Paris, Everett found that interfaith organizations did not question laïcité and its consequences for the identity of religious minorities in France whereas faith-based activities necessarily recognized the importance of religious identity and thus provided more opportunity for shared interfaith understanding. Echoing Bock's observations in Germany, cuts to welfare services have also had implications for interfaith relations and minority communities. Citing the Jewish community as an example, Everett notes how economic insecurity has led to greater reliance on Jewish community services, reinforcing insularity and anxiety about anti-Jewish violence. Public sector agencies have reinforced the perception of isolation by referring religious Jews in particular to Jewish organizations, despite the allegedly neutral status of public services.

At the same time, though, both Jewish and Muslim organizations provide a space of interfaith encounter that Everett argues is more effective than organizations explicitly targeting racism. For instance, the Jewish agency CASIP relies upon non-Jewish frontline staff to deliver its services, as there are too few Jewish social workers to recruit. The Muslim organization SIF has undergone a process of professionalization to ensure intergenerational sustainability, in turn creating opportunities for engagement with other civil society organizations. Everett concludes, repeating in a sense Artaud de la Ferriere's association of institutionalization with capacity for political activism (or, inversely, informality with lack of activism), that the interfaith interactions within and across faith-based organizations show how the concept of laicite should evolve, or to encompass more explicitly freedom of religious expression.

The last article also concerns France, but offers an alternative example to social action of religious expression in cross-faith social relations. Hanane Karimi explores how Muslim women have become entrepreneurs in order to practice freely their faith in the workplace rather than submit to anti-religious regulation. The humiliation they had felt in other jobs had led them to seek their own opportunities, or to be in control of their own rules and regulations. 


\section{References}

Ashcroft, B., et al. (1995). The post-colonial studies reader. London: Routledge Press.

Cohen, S. (2004). Searching for a different future. Durham: Duke University Press.

Gilman, H. R. (2017). The Moment for Participatory Democracy, Stanford Social Innovation Review, April 17, 2017.

Goodwin, M. (2011). Right response: understanding and countering populist extremism in Europe. London: Chatham House.

Goodwin, M. (2017). Shocked by populism? You shouldn't be, Financial Times, March 29, 2017.

Goodwin, M., \& Milazzo, C. (2017). Taking back control? Investigating the role of immigration in the 2016 vote for Brexit. The British Journal of Politics and International Relations [Online], 19, 450-464.

Guia, A. (2016). The concept of nativism and anti-immigrant sentiments in Europe. Florence: EUI Working Papers.

Martinelli, A. (Ed.). (2016). Beyond populism on the rise. Rome: Edizioni Epoké.

Mudde, C. (2007). Populist radical right parties in Europe. Cambridge: Cambridge University Press.

Mudde, C. (2012). The relationship between immigration and nativism in Europe and North America. Washington, DC: Migration Policy Institute.

Mudde, C. (2017). Why nativism, not populism, should be the declared word of the year, The Guardian. December 7, 2017. 